Journal of Environmental Science and Public Health

doi: $10.26502 /$ jesph.96120042

Volume 2, Issue 4

Research Article

\title{
Comparative Microbial Analysis of Borehole Water and other Sources of Water in Benin Metropolis, Edo State
}

\author{
Onajite C Idibie $^{1 *}$, Onome E Oviojie ${ }^{2}$, Oluwatoyin F Isalar ${ }^{2}$, Alexander O Emoghene ${ }^{1}$ \\ ${ }^{1}$ Department of Microbiology, University of Benin, Edo State, Nigeria \\ ${ }^{2}$ Department of Biological Sciences, Edwin Clark University, Delta State, Nigeria \\ *Corresponding Author: Onajite C Idibie, Department of Microbiology, University of Benin, Benin City, P.M.B \\ 1154, Edo State, Nigeria, E-mail: onodjikejitex@yahoo.com
}

Received: 26 November 2018; Accepted: 07 December 2018; Published: 13 December 2018

\begin{abstract}
The comparative microbial analysis of borehole water and other sources of water in Benin metropolis, Edo state was carried out to ascertain the variation of the water quality of the different sources using standard microbiological techniques. Eight different water sources were used, which include; well waters in Ologbo and Owa, river waters in Ogbekpan and Ikpoba, rainwaters in Uwelu and Isihor, and borehole waters in Uwelu and Isihor, respectively. The mean bacteria counts ranged from $2 \times 10^{4}$ to $32 \times 10^{4}$, where the highest mean bacteria counts were observed at both Ologbo well water and Ikpoba river water. The lowest mean bacteria count was however, observed at Isihor borehole water. Bacteria counts obtained from this study were found to be higher than the accepted limit of WHO standard in all the various water samples considered. The total coliform counts ranged from $6 \mathrm{MPN} / \mathrm{ml}$ to 61 $\mathrm{MPN} / \mathrm{ml}$ where the highest value was recorded in river water at Ogbekpan and lowest at Isihor borehole water. The mean faecal coliform counts were highest at Ogbekpan river water with a value of $24.7 \mathrm{MPN} / \mathrm{ml}$ and lowest at Uwelu rain water with a value of $0.3 \mathrm{MPN} / \mathrm{ml}$, respectively). The highest mean value of fungi was obtained from rain water Uwelu with a value of $7.3 \times 10^{4} \mathrm{cfu} / \mathrm{ml}$.
\end{abstract}

Keywords: Water; Bacteria; Fungi; Coliform; Culture media; Nutrient agar; Gram staining 


\section{Introduction}

Water is the most vital element among the natural resources and the most indispensable need for existence of all living things [1]. Its decreasing availability both in quality and quantity has been a major public health concern in Africa, particularly in Nigeria [2,3]. No gain saying that shortage of water leads to disease outbreak and economic loss, hence water is a necessity. In a nutshell without water life is impossible. Water plays a vital role in the proper functioning of the earth's ecosystem [4]. Globally, water is known to be a scarce resource and it has been estimated that 41 of the world's population (2.3 billion people) live under water stress condition. While 1.1 billion people live without access to potable water [5]. However, access to clean water is worse in developing countries, having one third of the population without access to safe drinking water and thus, leaving near 1.87 million children to die from diarrhoea annually [6]. The quality of water for drinking deteriorates due to poor treatment plants, direct discharge of untreated sewage into rivers and stream, and inefficient management of piped borne water distribution system [7]. The contaminated water therefore has critical impact on all biotic components of the ecosystem and this could affect its use for other purposes [4]. Most of drinking water sources are often contaminated with different pollutants such as faeces, animal and plant wastes, and thus making such water unfit for drinking if not treated. In developing countries such as Nigeria, especially in Benin metropolis where there is near extreme water scarcity, while rural communities lack access to potable water supply thus rely mainly on river and stream sources that are often unhealthy for their household use and other purposes [8], others that can afford boreholes rely on boreholes water. The use and consumption of this unsafe water primarily due to microbial presence, leads to diseases and ultimately death among the people with their attendant negative effects on the economy. There is therefore, the need to subject potable water to microbiological examination and WHO has recommended that increased emphasis be placed on home water treatment. A considerable number of authors have reported a statistically significant deterioration in the microbiological quality of water between the source and point use at homes $[9,10]$. Therefore, this study aims to carryout microbial analysis of the different water sources used by the people of Edo metropolis to determine their potability for consumption and other uses.

\section{Materials and Methods}

\subsection{Study area}

Benin metropolis is located in Edo state of Nigeria. It is reported to have a geographical coordinates of $6^{\circ} 20^{\prime} 0^{\prime \prime}$ North, $5^{\circ} 38^{\prime} 0^{\prime \prime}$ East. Benin City is known to be situated on a branch of the Benin River and lies along the main highways from Lagos to the Niger bridge at Asaba and the eastern states. The city is also linked by roads to Sapele, Siluko, Okene, and Ubiaja and is served by air and the Niger River delta ports of Koko and Sapele [11].

\subsection{Samples collections, transport and storage}

Water samples for analysis were collected in sterile containers and in the process, special care was taken to obtain fair samples. For samples collected from rivers and well, the sample bottles were filled from below the surface of the water to avoid sediments, while samples from the tap were taken after allowing the tap to run for about five minutes. Water samples were collected from eight different sources namely; borehole water samples from Isihor and Uwelu, 
rain water samples from Isihor and Uwelu, river water samples from Ikpoba and Ogbekpan, and the well water from Ologbo and Owa, respectively. The samples were majorly analyzed for microbial and biochemical analysis. However, all samples were transported to the laboratory in ice-bag and processed within 6 hours of collection.

\subsection{Preparation of culture media}

The media used were prepared according to the manufacturer's instructions. They were nutrient agar (NA) and potato dextrose agar (PDA).

2.3.1 Nutrient agar: Twenty-eight gram ( $28 \mathrm{~g})$ of nutrient agar (NA) powder was dissolved in 1 litre of distilled water in a conical flask covered with cotton wool and aluminium foil paper. It was mixed thoroughly and sterilized by autoclaving at $121^{\circ} \mathrm{C}$ for 15 minutes and was cooled to $45-50^{\circ} \mathrm{C}, 20 \mathrm{ml}$ was dispensed aseptically into sterile Petri dishes.

2.3.2 Potato dextrose agar: Thirty-nine grams ( $39 \mathrm{~g}$ ) of potato dextrose agar (PDA) powder was dissolved in 1 litre of distilled water in a conical flask covered with cotton wool and aluminium foil paper. It was mixed thoroughly and sterilized by autoclaving at $121^{\circ} \mathrm{C}$ for 15 minutes. The medium was cooled to $45-50^{\circ} \mathrm{C}$ and then dispensed aseptically into sterile Petri dishes.

\subsection{Microbiological parameters}

2.4.1 Total counts of heterotrophic microorganism (bacteria): Total heterotrophic bacteria counts were isolated using Nutrient agar (NA) by pour plate method. Aliquot of $1 \mathrm{ml}$ of the $10^{-4}$ dilutions of the samples was used to incubate the plate in triplicates; the plates were incubated at $37^{\circ} \mathrm{C}$ for $48 \mathrm{hrs}$. Thereafter the mean counts of the bacteria colonies were taken. The bacteria isolates were further experimented in order to attain pure cultures. The pure cultures were then characterized and identified to determine the bacteria species using the standard microbial method.

2.4.2 Total coliform counts and total faecal coliform counts: The coliform counts were determined by the most probable number (MPN) techniques. Samples were incubated in Lactose broth tubes at $37^{\circ} \mathrm{C}$ for $48 \mathrm{hrs}$. Measured amounts of double and single strength MacConkey broth (purple colour) were sterilized in bottles containing inverted Durham tube to indicate the gas production. The bottles were arranged in three sets $50 \mathrm{ml},(10 \mathrm{ml}$ and $1 \mathrm{ml}$ and each had 5 bottles), and incubated at $37^{\circ} \mathrm{C}$. Fermentation tubes were incubated with $50 \mathrm{ml}, 10 \mathrm{ml}$ and $1 \mathrm{ml}$ of aliquot of the samples in accordance with standard methods [12]. The tubes were incubated at $37^{\circ} \mathrm{C}$ for $48 \mathrm{hrs}$. Positive tubes producing acid and gas were used to estimate the presumptive Most Probable Number (MPN). The confirmed test for total coliform was achieved by plating a loopful of positive MacConkey broth on Eosine Methylene Blue (EMB) agar and incubated at $37^{\circ} \mathrm{C}$ for $24 \mathrm{hrs}$, while the faecal coliform was achieved by transferring a loopful of broth from a positive tube to $\mathrm{EC}$ broth and incubated at $44.5^{\circ} \mathrm{C}$ for $24-48 \mathrm{hrs}$ and the tubes were observed for gas formation. Completed test for faecal coliform was carried out by plating a loopful of broth from a 
positive EC tube unto an Eosine methylene blue agar plate. The plates were incubated at $44.5^{\circ} \mathrm{C}$ for 48 hrs and observed for a dark red colour with metallic green sheen. Stock cultures of the colonies of the total and faecal coliforms were prepared on nutrient agar slants and colonies were used for Gram staining and biochemical test. Final faecal coliform of Escherichia coli count as MPN/ml was calculated based on the completed test.

2.4.3 Fungi: Aliquot of $1 \mathrm{ml}$ of $10^{-4}$ dilution of the sample were inoculated into potato dextrose agar (PDA) in triplicate and incubated at $28^{\circ} \mathrm{C}$ for $72 \mathrm{hrs}$. Thereafter the developing colonies were counted and the mean values were thus determined.

\subsection{Pure culture}

One single colony was identified and re-streaked as a primary inoculant on the surface of a nutrient agar plate medium. Pure cultures were checked from nutrient agar plates. After achieving a pure culture, the same colony was streaked onto a nutrient agar slant. These cultures were incubated at $37^{\circ} \mathrm{C}$ for 1 day and further kept in the refrigerator.

\subsection{Cultural characteristics}

Each colony morphology e.g. size, shape, margin, elevation, consistency, colour, transparency was determined.

\subsection{Morphological test}

2.7.1 Fungi morphology: Fungal growth on plate culture was observed; surface, spore and underside colour. Stained (lactophenol cotton blue) slide was examined using a microscope $(\times 40)$ for structure of hyphae and details of sporulating structure.

2.7.2 Gram staining: Smears of the isolates were prepared and heat fixed on clean grease free slides. The smears were stained for one minute with crystal violet. This was washed out with distilled water. The slides were flooded with dilute Grams iodine solution for one minute. This was washed off with distilled water and the smears were decolorized with $95 \%$ alcohol for 30 seconds and rinsed off with distilled water. The smears were then counter stained with saffranin solution for one minute. Finally, the slides were washed off with distilled water, air dried and observed under oil immersion objective.

\subsection{Biochemical test}

2.8.1 Catalase test: This is a test to detect the presence or absence of catalase enzyme. The catalase enzyme catalyses the breakdown of hydrogen peroxide to release free oxygen gas and the formation of water. A few drops of freshly prepared $3 \%$ hydrogen peroxide were added onto the bacteria isolates smeared on a slide. The production of gas bubble indicate indicates presence of catalase enzyme. 
2.8.2 Oxidase test: A piece of filter paper was wet with a few drops of the dilute (1\%) solution of oxidase reagent (tetramethyl-phenylenediamine-dihydrochloride) which was prepared by standard procedure. A bit of growth from the nutrient agar slant was obtained using sterilized platinum wire loop and smeared on the wet piece of paper. Development of an intense purple colour by the cells within 30 seconds indicates a positive oxidase test.

2.8.3 Coagulase test: Coagulases are enzymes that clot blood plasma and they produced by Staphylococcus aureus. The enzyme protease converts fibrinogen to fibrin resulting to blood clotting. The Slide method was used. Here, clean slide was divided into two sections, to one section the test organism was smeared on it using a sterile wire loop while a drop of distilled water was added to the other section serving as control. Then human plasma was added to both sections and the slide was rocked gently for some minutes. A clumping/agglutination of the plasma indicates the presence of coagulase.

2.8.4 Urease test: The bacteria isolates were inoculated into slants of urea medium and incubated at $37^{\circ} \mathrm{C}$ for $24-48$ hours. Red-pink colour indicates presence of Urease cultures.

2.8.5 Indole test: This test was used to determine which of the isolates has the ability to split indole from tryptophan present in buffered peptone water. The test is used to differentiate Gram-negative Bacilli especially those of the enterobacteriaceae. Peptone water was prepared and about $3 \mathrm{ml}$ of it was dispensed in bijou tubes using a sterile pipette. Then, fresh sterile loops were used to pick a well-isolated colony of bacteria and inoculated into bijou tubes, thereafter, the tubes were incubated at $37^{\circ} \mathrm{C}$ for 48 hours. After incubation period, $0.5 \mathrm{ml}$ of Kovac's Indole Reagent was added to the inoculated bijou tubes and gentle shaken. A red ring was examined in the surface layer within 10 minutes which indicated indole positive reaction.

2.8.6 Citrate utilization test: This test is based on the ability of some organisms to utilize citrate as a sole source of carbon. It was carried out by inoculating the test organism in test tube containing Simon's citrate medium and incubated at $37^{\circ} \mathrm{C}$ for $24-48$ hours. A deep blue colour indicates a positive result.

2.8.7 Sugar fermentation test: Each of the isolates was tested for its ability to ferment a given sugar with the production of acid and gas or acid only. Since most bacteria especially Gram negative bacteria utilize different sugars as source of carbon and energy with the production of both acid and gas or acid only, the test is used as an aid in their differentiation. The growth medium used was peptone water and the peptone water was prepared in a conical flask and the indicators; phenol red was added. The mixture was dispensed into test tubes containing Durham tubes and sterilized by autoclaving at $121^{\circ} \mathrm{C}$ for 15 minutes. $1 \%$ solution of the sugar was prepared and sterilized separately at $115^{\circ} \mathrm{C}$ for 10 minutes. This was then ascetically dispensed in $5 \mathrm{ml}$ volume into the tubes containing the peptone water and indicator. The tubes were inoculated with young culture of the isolates and incubated at $37^{\circ} \mathrm{C}$. Acid and gas production or acid only were observed after about 24 hours of incubation. Acid production was 
indicated by the change of the medium from light green to yellow colour while gas production was indicated by the presence of gas in the Durham's tubes.

\section{Results}

The mean values and standard deviation of the bacteria counts of the various water samples at different locations are shown in Table 1.

\begin{tabular}{|l|l|}
\hline Water Source & Total Bacteria Counts $(\mathbf{c f u} / \mathbf{m l})$ \\
\hline W1 & $32.0 \pm 7.35 \times 10^{4}$ \\
\hline W2 & $8.7 \pm 2.05 \times 10^{4}$ \\
\hline W3 & $11.3 \pm 5.79 \times 10^{4}$ \\
\hline W4 & $12.3 \pm 2.87 \times 10^{4}$ \\
\hline W5 & $5.0 \pm 1.63 \times 10^{4}$ \\
\hline W6 & $9.0 \pm 4.55 \times 10^{4}$ \\
\hline W7 & $4.7 \pm 0.47 \times 10^{4}$ \\
\hline W8 & $2.0 \pm 0.82 \times 10^{4}$ \\
\hline
\end{tabular}

Key: W1=Well water-Ologbo; W2=Well water-Owa; W3=River water-Ogbekpan; W4=River water-Ikpoba; W5=Rainwater-Uwelu; W6=Rain water-Isihor; W7=Borehole water-Uwelu; W8=Borehole water-Isihor.

Table 1: Mean values of the bacteria counts of the various water sources.

\begin{tabular}{|l|l|}
\hline Water Source & Total Fungi Counts $\mathbf{c f u} / \mathbf{m l})$ \\
\hline W1 & $0.3 \pm 0.47 \times 10^{4}$ \\
\hline W2 & $4.7 \pm 1.25 \times 10^{4}$ \\
\hline W3 & $21.7 \pm 8.58 \times 10^{4}$ \\
\hline W4 & $32.0 \pm 2.40 \times 10^{4}$ \\
\hline W5 & $7.3 \pm 1.25 \times 10^{4}$ \\
\hline W6 & $1.67 \pm 0.47 \times 10^{4}$ \\
\hline W7 & 0 \\
\hline W8 & $0.3 \pm 0.47 \times 10^{4}$ \\
\hline
\end{tabular}

Key: W1=Well water-Ologbo; W2=Well water-Owa; W3=River water-Ogbekpan; W4=River water-Ikpoba; W5=Rainwater-Uwelu; W6=Rain water-Isihor; W7=Borehole water-Uwelu; W8=Borehole water-Isihor.

Table 2: Mean values of the fungi counts of the various water sources.

Table 3 is the results of microbial coliform counts of the various water sources while Table 4 represents the values of faecal coliform counts of the various water sources. 


\begin{tabular}{|l|l|}
\hline Water Source & Total Coliform Counts $(\mathbf{M P N} / \mathbf{m l})$ \\
\hline W1 & $30.3 \pm 15.8$ \\
\hline W2 & $22.0 \pm 9.9$ \\
\hline W3 & $61.0 \pm 19.2$ \\
\hline W4 & $29.7 \pm 13.2$ \\
\hline W5 & $7.3 \pm 1.25$ \\
\hline W6 & $9.0 \pm 2.9$ \\
\hline W7 & $7.0 \pm 2.4$ \\
\hline W8 & $6.0 \pm 1.6$ \\
\hline
\end{tabular}

Key: W1=Well water-Ologbo; W2=Well water-Owa; W3=River water-Ogbekpan; W4=River water-Ikpoba; W5=Rainwater-Uwelu; W6=Rain water-Isihor; W7=Borehole water-Uwelu; W8=Borehole water-Isihor.

Table 3: Mean values of microbial coliform counts of the various water sources.

\begin{tabular}{|l|l|}
\hline Water Source & Total Coliform Counts (MPN/ml) \\
\hline W1 & $8.3 \pm 0.2$ \\
\hline W2 & $11.0 \pm 4.5$ \\
\hline W3 & $24.7 \pm 8.6$ \\
\hline W4 & $13.7 \pm 4.9$ \\
\hline W5 & $0.3 \pm 0.4$ \\
\hline W6 & $1.7 \pm 0.4$ \\
\hline W7 & $2.0 \pm 0.4$ \\
\hline W8 & $5.3 \pm 1.3$ \\
\hline
\end{tabular}

Key: W1=Well water-Ologbo; W2=Well water-Owa; W3=River water-Ogbekpan; W4=River water-Ikpoba; W5=Rainwater-Uwelu; W6=Rain water-Isihor; W7=Borehole water-Uwelu; W8=Borehole water-Isihor.

Table 4: Mean values of faecal coliform counts of the various water sources.

Tables 5 and 6 present the frequency occurrences of both bacteria and fungi in different water sources.

\begin{tabular}{|l|l|l|l|l|l|l|l|l|}
\hline Isolate & W1 & W2 & W3 & W4 & W5 & W6 & W7 & W8 \\
\hline Esherichia coli & + & - & + & + & - & - & - & + \\
\hline Staphylococcus epidermidis & - & + & - & - & + & - & - & - \\
\hline Streptococcus spp. & - & + & - & + & - & + & - & - \\
\hline Micrococcus luteus & + & - & + & + & + & - & + & + \\
\hline Enterobacter spp. & - & + & + & + & + & + & + & + \\
\hline
\end{tabular}




\begin{tabular}{|l|l|l|l|l|l|l|l|l|}
\hline Staphylococcus aureus & + & - & + & + & - & - & - & - \\
\hline Enterococcus spp & + & - & + & - & - & - & - & - \\
\hline
\end{tabular}

Table 5: Frequency of occurrence of bacteria isolates from different water sources.

\begin{tabular}{|l|l|l|l|l|l|l|l|l|}
\hline Isolate & W1 & W2 & W3 & W4 & W5 & W6 & W7 & W8 \\
\hline Trichoderma spp. & - & + & + & - & - & - & - & - \\
\hline Aspergillus flavus & - & + & + & + & - & + & - & - \\
\hline Aspergillus niger & - & - & + & - & + & - & - & - \\
\hline Penicillium spp. & + & + & + & + & + & + & - & - \\
\hline Mucor & - & - & - & + & - & - & - & + \\
\hline
\end{tabular}

Table 6: Frequency of occurrence of fungi isolates from different water sources.

While Tables 7 and 8 are the Percentage (\%) frequency of distribution of both bacteria and fungi isolates from the different water sources.

\begin{tabular}{|l|l|}
\hline Bacteria Isolates & Percentage (\%) Frequency of Distribution \\
\hline Escherichia coli & 8.5 \\
\hline Staphylococcus aureus & 10.0 \\
\hline Staphylococcus epidermidis & 22.7 \\
\hline Micrococcus luteus & 15.8 \\
\hline Enterobacter spp. & 26.9 \\
\hline Streptococcus spp. & 10.4 \\
\hline Enterococcus spp. & 5.7 \\
\hline
\end{tabular}

Table 7: Percentage (\%) frequency of distribution of bacteria isolates from the different water sources.

\begin{tabular}{|l|l|}
\hline Fungi Isolates & Percentage (\%) Frequency of Distribution \\
\hline Trichoderma spp. & 12.5 \\
\hline Aspergillus flavus & 25 \\
\hline Aspergillus niger & 16.5 \\
\hline Penicillium spp. & 37.5 \\
\hline Mucor & 8.5 \\
\hline
\end{tabular}

Table 8: Percentage (\%) frequency of distribution of fungi isolates from the different water sources. 


\section{Discussion}

In this research, the mean total bacteria counts were between $2.0 \times 10^{4} \mathrm{cfu} / \mathrm{ml}$ in borehole water at Isihor and $32.0 \times$ $10^{4} \mathrm{cfu} / \mathrm{ml}$ in well water at Ologbo, indicating high level of pollution of the well water due to human and animal activities (Table 1). These counts are higher than the acceptable counts of $0 \mathrm{cfu} / \mathrm{ml}$ for drinking water [13]. The higher total bacteria counts especially in the two well waters at Ologbo and Owa, and the two river waters at Ogbekpan and Ikpoba is an indication of the presence of high organic matter in the water. The main source of these bacteria in the waters can be attributed to both human animal activities [14]. These sources of bacteria contamination include surface runoff, animal waste deposition and pasture. Other human activities like swimming, waste disposal, domestic activities and faecal discharge [1] are also possible ways of introducing foreign microorganisms in the water thereby making more nutrients available for the microorganisms in the water thus enhancing their growth at all the various water sources. The mean total fungi counts were between $0.33 \times 10^{4} \mathrm{cfu} / \mathrm{ml}$ in Ologbo well water and Isihor borehole water to $32 \times 10^{4}$ in Ikpoba river water (Table 2). Human activities are responsible for the high microbial counts in Ikpoba river water which results in the disturbance of the already contaminated sediments arising in possible nutrient release [15].

The results of the total coliform counts (TCC) (Table 3) exceeded that of the WHO standard for coliform bacteria in water, which is zero total coliform per $100 \mathrm{ml}$ of water. The result showed that the total coliform counts for all the various water sources where the least coliform counts was recorded at Isihor borehole water $(6.0 \mathrm{MPN} / \mathrm{ml})$ and the highest total coliform counts was $61.0 \mathrm{MPN} / \mathrm{ml}$ in river water at Ogbekpan while the faecal coliform counts ranged from 0.3 MPN $/ \mathrm{ml}$ to $24.7 \mathrm{MPN} / \mathrm{ml}$ (Table 4). Faecal coliforms were higher in the river waters (Ologbo river water and Ogbekpan river water) which could be attributed to the discharge of sewage into the rivers by the surrounding people. The presence of coliform counts obtained from the samples is an indication of faecal contamination. None of the samples complied with the WHO standard for coliform in water, and this is in agreement with previous work by Benka-Coker et al. [16], who had earlier reported high microbial counts on water containing higher organic matter. According to WHO [17], any water sample that contains coliform should be investigated for the presence of faecal coliforms [18].

The result also showed that seven bacteria isolates were isolated from the various water samples, which include Escherichia coli, Staphylococcus epidermidis, Streptococcus spp., Micrococcus luteus, Enterobacter spp., Staphylococcus aureus and Enterococcus luteus, Table 5 showed the frequency of distribution of the bacteria isolates, where Enterobacter spp. and Staphylococcus epidermidis are the most prevalent isolates, and the least prevalent were Enterococcus luteus. and Escherichia coli. Escherichia coli was not isolated from the two rain waters analyzed. Enterobacter spp. isolated from the water samples are non-faecal coliforms which can be found in vegetation and soil, which serve as potential source by which microorganisms can enter the water body. The polluted water may be due to water runoff from farm lands carrying manures, pesticides, animal and human waste matter. A total of five fungi isolates were identified, which include Penicillium spp., Aspergillus niger, Aspergillus flavus, Trichoderma spp. and Mucor. The values of the fungi counts obtained were observed to be highest for both 
river waters, however, low values were recorded for well water at Ologbo and borehole water at Isihor. It is interesting to note that no growth was recorded at Uwelu borehole water. The percentage frequency of bacteria isolated ranged from $26.9 \%$ to $5.7 \%$ as shown in Table 7 . The result shows that Enterobacter spp. had the highest value while Enterococcus spp. had the lowest value. For the fungi isolated, Penicillium spp. had the highest value of $37.5 \%$ while Mucor had the lowest value of $8.5 \%$ as shown in Table 8 .

\section{Conclusion}

The results obtained from this study show that the various water sources considered are contaminated with biological and agents of human and animal origins. However, the two borehole waters and two rain waters are comparatively better water than the two well waters and the two river waters. The high microbial load particularly in well water at Ologbo and the two river waters make them unsuitable for drinking purposes, although they can be used for washing purposes.

\section{References}

1. Egberongbe HO, Bello OO, Solate AT, et al. Microbiological evaluation of stream water for domestic use in rural areas: A case study of Ijebu North Local government, Ogun state, Nigeria. Journal of Natural Sciences, Engineering and Technology 11 (2012): 93-103.

2. World Health Organisation (WHO). Water Sanitation and Health Programme. Managing water in the home: accelerated health gains from improved water sources. Flourosis and Sanitation 11 (2004): 7-11.

3. Saravanan S, Peter M. Water pollution and man health. Centre for Development Research. Germany (2009): $1-5$.

4. Ajayi AO, Adejumo TO. Microbiological assessment and some physico-chemical properties of water sources in Akungba-Akoko, Nigeria. Journal of Toxicology and Environmental Health Sciences 3 (2011): $342-346$.

5. Fitzmaurice M. The human right to water. Fordham Environmental Law Review 18 (2007): 37-573.

6. Boschi-Pinto C, Velebit L, Shibuya K. Estimating child mortality due to diarrhoea in developing countries. Bulletin of the World Organization 86 (2008): 710-717.

7. UNEP. State of Water Sanitation and Health Programme Nepal. United Nation Environment Programme (UNEP) (2001).

8. Banwo K. Nutrient Load and Pollution Study of some selected Stations along Ogunpa River in Ibadan, Nigeria. African Journal of Microbiology 25 (2006): 7-11.

9. Simango C, Dindiwe J, Rukure G. Bacterial contamination of food and household stored drinking water in farmworker community in Zimbabwe. Central Afri J Med 38 (1992): 143-149.

10. Welch P, David J, Clarke W, et al. Guideline of drinking water quality, $2^{\text {nd }}$ ed. Health Criteria and other supporting information. WHO, Geneva, Switzerland (1993): 162.

11. Encyclopedia Britainica. Benin city, Nigeria. Encyclopedia Britainica Inc (2018).

12. American Public Health Associated (APHA). Standard method for examination of water and waste water, 
$20^{\text {th }}$ Edn. American Public Health Associated Inc, New York (1995).

13. Nigerian Industrial Standard (NIS). Nigerian standard for drinking water quality. NIS (2007): 554.

14. Scott TM, Salina P, Rose KM, et al. Geographical variation in ribotype profiles of Escherichia coli isolates from humans, swine, poultry, beef and dairy cattle in Florida. Applied Environmental Microbiology 69 (2003): 1089-1092.

15. Valent PJ, Young DK, Sawyer WB, et al. Abyssal seafloor water isolations; the concept. Journal of Microbiological System 14 (1998): 203-210.

16. Benka-Coker MO, Ohimain EI. Investigation of spatial variations in bacteria distribution in surface water in Ikpoba river. Nigerian Journal of Microbiology 10 (1995): 27-32.

17. World Health Organization (WHO). Guidelines for drinking water quality 2 (1996): 68.

18. European Union (EU). Council directive on the quality of water intended for human consumption. Journal of European Communication 330 (1998): 32-54.

Citation: Onajite C Idibie, Onome E Oviojie, Oluwatoyin F Isalar, Alexander O Emoghene. Comparative Microbial Analysis of Borehole Water and other Sources of Water in Benin Metropolis, Edo State. Journal of Environmental Science and Public Health 2 (2018): 232-242.

This article is an open access article distributed under the terms and conditions of the Creative Commons Attribution (CC-BY) license 4.0 